\title{
USULAN PENINGKATAN EFEKTIVITAS TENAGA KERJA DENGAN MENGGUNAKAN METODE OVERALL LABOR EFFECTIVENESS
}

\author{
${ }^{1}$ Vera Devani, ${ }^{2}$ Syafruddin \\ ${ }^{1,2}$ Program Studi Teknik Industri, Fakultas Sains dan Teknologi, UIN SUSKA Riau, \\ J1. HR Soebrantas, KM. 18.5, No. 155, Simpang Baru, Pekanbaru, Indonesia, 28293. \\ Email: ${ }^{1}$ veradevani@gmail.com, ${ }^{2}$ syafruddin@uin-suska.ac.id.
}

\begin{abstract}
ABSTRAK
Overall Labor Effectiveness (OLE) adalah indikator kinerja kunci yang mengukur utulitas, kinerja, dan kualitas tenaga kerja beserta dampaknya terhadap produktivitas. Indikator untuk mengukur nilai OLE adalah ketersediaan (availability), kinerja (performance), dan kualitas (quality). Tujuan dari penelitian ini adalah untuk menentukan nilai Overall Labor Effectiveness (OLE), menentukan akar penyebabnya dan usulan perbaikan. Berdasarkan hasil penelitian diperoleh nilai OLE tertinggi pada bulan Juli yaitu, 92,9\% sedangkan nilai terendah pada bulan Agustus yaitu 72,9\%. Nilai availability 54,2\%-79,4\%, performance 62,9-100\%, dan quality 98,8\%-99,6\%. Dari ketiga indikator dalam menentukan nilai OLE terlihat bahwa nilai terendah terdapat pada nilai availability. Untuk meningkatkan nilai OLE, faktor tenaga kerja harus mendapat perhatian dengan cara mengurangi tingkat ketidakhadiran. Usulan untuk peningkatan nilai OLE kepada perusahaan adalah melakukan pelatihan secara berkala, memotivasi karyawan dan melakukan pengawasan terhadap karyawan, sedangkan untuk memenuhi target perusahaan sebaiknya dilakukan penempatan tenaga kerja yang sesuai dengan keahliannya.
\end{abstract}

Kata Kunci: diagram pohon, efektivitas kerja, overall labor effectiveness

\section{A. PENDAHULUAN}

Dampak yang harus dihadapi oleh perusahaan manufaktur adalah faktor kegagalan dalam memenuhi spesifikasi produk yang mengarah kepada permasalahan di lantai produksi seperti berkurangnya jumlah produksi dikarenakan faktor manusia (human factor) ataupun dikarenakan kurangnya perhatian terhadap pengendalian efektivitas dari kinerja tenaga kerja.Usaha peningkatan efektivitas kinerja merupakan salah satu mekanisme yang dapat terus ditingkatkan untuk mengimbangi kondisi tersebut.

PT. "Y" perusahaan yang bergerak di bidang pengolahan karet mentah menjadi barang setengah jadi (work in process) yang kemudian di ekspor ke luarnegeri. Jenis produk yang dihasilkan yaitu crumb rubber SIR-10 dan SIR-20 (Standart Indonesia Rubber) yang membedakan kedua SIR ini adalah kadar air yang berbeda. Berikut adalah grafik jumlah produksi crumb rubber selama 1 tahun.

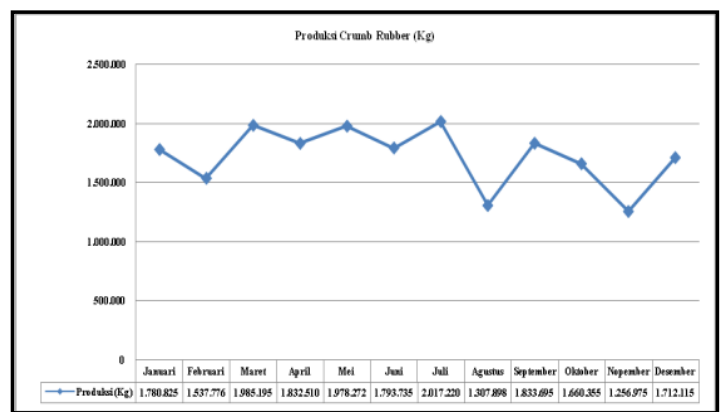

Gambar 1. Grafik jumlah produksi crumb rubber
Berdasarkan dari grafik jumlah produksi di atas, efektivitas kinerja PT. "Y" belum maksimal bila dibandingkan denganrata-rata produksi riel yang dihasilkan oleh tenaga kerja dengan target produksi perusahaan yaitu $24.000 .000 \mathrm{~kg}$ per tahun atau 2.000.000 kg per bulannya. Oleh karena jumlah produksi riil masih beradadi bawah target produksimaka perlukan langkah-langkah yang efektif dan efisien dalam pengendalian tenaga kerja untuk dapat menanggulangi dan mencegah masalah tersebut. Dimana telah diakui bahwa dengan memproduksi produk-produk yang bermutu tinggi telah meningkatkan pendapatan nasional sehingga membuat negara-negara itu berkembang pesat perekonomiannya

Overall Labor Effectiveness (OLE) adalah indikator kinerja kunci (KPI) yang mengukur utilisasi, kinerja, dan kualitas tenaga kerja beserta dampaknya terhadap produktivitas. OLE membantu perusahaan dalam mengambil tindakan untuk mengurangi biaya dan mengidentifikasi peluang untuk meningkatkan produktivitas secara keseluruhandan profitabilitas melalui pengukuran kontribusi dari tenaga kerja.

Penelitian tentang peningkatan efektivitas kerja melalui komitmen, perubahan dan budaya organisasi pernah dilakukan oleh [1]. Dari penelitian tersebut disimpulkan bahwa komitmen organisasi terhadap efektivitas kerja memiliki implikasi bahwa suatu kekuatan relatif setiap pegawai memiliki kecepatan dan ketepatan dalam penyelesaian tugas-tugas. Penelitian yang 
dilakukan oleh [6] tentang Analisa Pengaruh Sikap Kerja 5S dan Faktor Penghambat Penerapan 5S terhadap Efektivitas Kerja Departemen Produksi di Perusahaan Sepatu. Hasil penelitian menunjukkan seluruh variabel mempunyai hubungan (korelasi) yang cukup baik dengan efektifitas kerja sedangkan untuk sikap kerja 5S sendiri ternyata didapatkanhasil negatif dari analisis regresi berganda. Penelitian yang dilakukan bertujuan menentukan nilai Overall Labor Effectiveness dari tenaga kerja di bagian produksi dan menentukan akar penyebab dari permasalahan yang ada serta mengajukan usulan perbaikan.

\section{B. TINJAUAN PUSTAKA}

\section{B.1. Definisi dan Ukuran Efektivitas Kerja}

Efektivitas kerja terdiri dari kata efektivitas dan kerja. Efektivitas merupakan kemampuan untuk memilih tujuan atau peralatan yang tepat untuk pencapaian tujuan yang ditetapkan. Efektivitas adalahtingkat kemampuan untuk mencapai tujuan dengan tepat dan baik [3].

Mengukur efektivitas organisasi bukanlah suatu hal yang sangat sederhana, karena efektivitas dapat dikaji dari berbagai sudut pandang dan tergantung pada siapa yang menilai serta menginterpretasikannya. Bila dipandang dari sudut produktivitas, maka seorang manajer produksi memberikan pemahaman bahwa efektivitas berarti kualitas dan kuantitas (output) barang dan jasa.

Tingkat efektivitas juga dapat diukur dengan membandingkan antara rencana yang telah ditentukan dengan hasil nyata yang telah diwujudkan. Namun, jika usaha atau hasil pekerjaan dan tindakan yang dilakukan tidak tepat sehingga menyebabkan tujuan tidak tercapai.

Kriteria untuk pencapaian tujuan efektif atau tidak yaitu [3]:

(1) kejelasan tujuan yang hendak dicapai.Hal ini bertujuan agar tenaga kerja dalam melaksanakan tugas mencapai sasaran yang terarah agar tujuan organisasi dapat tercapai;

(2) kejelasan strategi pencapaian tujuan. Strategibertujuan untukmencapai sasaransasaran yang ditentukan agar para implementer tidak tersesat dalam pencapaian tujuan organisasi;

(3) proses analisis dan perumusan kebijakan yang baik.Kebijakan harus mampu menjembatani tujuan-tujuan dengan usaha-usaha pelaksanaan kegiatan operasional;

(4) perencanaan yang matang, yaitu memutuskan apa yang akan dikerjakan oleh organisasi dimasa depan;

(5) penyusunan program yang tepat;

(6) persedianya sarana dan prasarana kerja, salah satu indikator efektivitas organisasi adalah kemampuan bekerja secara produktif;

(7) pelaksanaan yang efektif dan efisien;
(8) sistem pengawasan dan pengendalian yang bersifat mendidik.

\section{B.2. Faktor yang Mempengaruhi Efektivitas Kerja \\ Faktor yang mempengaruhi tercapainya} efektivitas kerja, yaitu [4]:

(1) karakteristik organisasi, karakteristik organisasi terdiri dari struktur dan teknologi organisasi. Struktur merupakan cara untuk suatu organisasi menyusun orang-orangnya untuk menciptakan sebuah organisasi yang meliputi jumlah spesialisasi pekerjaan, desentralisasi pengendalian untuk penyelesaian pekerjaan;

(2) karakteristik lingkungan, lingkungan mencakup dua aspek yang berhubungan yaitu lingkungan intern dan ekstern. Lingkungan intern dikenal dengan iklim organisasi yang meliputi atribut lingkungan kerja seperti kepuasan dan prestasi. Lingkungan ekstern menyangkut kekuatan yang timbul diluar batas organisasi yang mempengaruhi tindakan dalam organisasi seperti adanya peraturan pemerintah;

(3) karakteristik pekerja, pekerja mempunyai pandangan, tujuan, kebutuhan dan kemampuan yang berbeda-beda sehingga akan menyebabkan perbedaan perilaku antara orang satu dengan orang lain;

(4) kebijakan dan praktek manajemen, manajer memegang peranan sentral dalam keberhasilan suatu organisasi melalui perencanaan, koordinasi dan memperlancar kegiatan.

\section{B.3. Indikator Efektivitas Kerja}

Indikator untuk mengukur efektivitas kerja menurut meliputi [5]:

(1) kemampuan menyesuaikan diri, kemampuan manusia terbatas dalam segala hal, sehingga dengan keterbatasannya itu menyebabkan manusia tidak dapat mencapai pemenuhan kebutuhannya tanpa melalui kerjasama dengan orang lain;

(2) prestasi kerja, prestasi kerja adalah suatu hasil kerja yang dicapai seseorang dalam melaksanakan tugas-tugas yang dibebankan kepadanya yang didasarkan atas kecakapan, pengalaman, kesungguhan dan waktu.

Dari pendapat diatas dapat disimpulkan bahwa prestasi kerja adalah hasil yang dicapai oleh seorang pekerja dalam menyelesaikan pekerjaannya yangbermutu dengan batas waktu yang telah ditentukan.

\section{B.4. Produktivitas}

Beberapa pengertian produktivitas dapat diuraikan sebagai berikut [6]: 
(1) menurut Organization for Economic and Development (OECD), menyatakan bahwa pada dasarnya produktivitas adalah output dibagi dengan elemen produksi yang dimanfaatkan;

(2) menurut International Labour Organization (ILO) menyatakan bahwa pada dasarnya produktivitas adalah perbandingan antara elemen-elemen produksi dengan yang dihasilkan. Elemen-elemen tersebut berupa tanah, tenaga kerja, modal dan organisasi;

(3) menurut European Productivity Agency (EPA) menyatakan bahwa pada dasarnya produktivitas adalah tingkat efektivitas pemanfaatan setiap elemen produktivitas;

(4) menurut formulasi dari National Productivity Board, Singapore, pada dasarnya produktivitas adalah sikap mental (attitude of mind) yang mempunyai semangat untuk bekerja keras dan ingin memiliki kebiasaan untuk melakukan peningkatan perbaikan.

Dari definisi produktivitas di atas, dapat disimpulkan bahwa produktivitas adalah perbandingan antara hasil yang dicapai (output) dengan keseluruhan sumber daya yang digunakan (input).

Peningkatan produktivitas pada dasarnya dapat dikelompokkan yaitu sebagai berikut [7]:

(1) pengurangan sedikit sumber daya untuk memperoleh jumlah produksi yang sama;

(2) pengurangan sumber daya sekedarnya untuk memperoleh jumlah produksi yang lebih besar;

(3) penggunaan jumlah sumber daya yang sama untuk memperoleh jumlah produksi yang lebih besar;

(4) penggunaan jumlah sumber daya yang lebih besar untuk memperoleh jumlah produksi yang jauh lebih besar lagi.

Untuk menambah output diperlukan nilai tambah produk yang lebih besar dan inovasi produk. Sedangkan untuk mengurangi input dapat dilakukan dengan mengurangi biaya tenaga kerja, mengurangi biaya pabrik dan peralatan produksi, serta mengurangi biaya bahan baku.

\section{B.5. Definisi dan Pengukuran Kinerja}

Kinerja adalah sepadan dengan prestasi kerja actual performnce, yang merupakan hasil secara kualitas dan kuantitas yang dicapai oleh seorang karyawan dalam melaksanakan tugasnya sesuai dengan tanggungjawab yang diberikan kepadanya [8]. Kinerja (performance) adalah hasil kerja yang konkrit, dapat diamati, dan dapat diukur Dengan demikian kinerja merupakan hasil kerja yang dicapai oleh karyawan dalam melaksanakan tugas berdasarkan ukuran dan waktu yang telah ditentukan.
Kinerja karyawan adalah hasil kerja secara kualitas dan kuantitas yang dicapai oleh seorang karyawan dalam melaksanakan tugasnya sesuai dengan tanggung jawab yang diberikan [9]. Suatu pekerjaan dapat diukur melalui kuantitas dan kualitas pekerjaan, ketepatan waktu, kehadiran dan kemampuan kerja sama [10]. Kinerja karyawan dipengaruhi oleh tiga faktor, yakni:

(1) faktor individual terdiri dari kemampuan dan keahlian, latar belakang dan demografi;

(2) faktor psikologis terdiri dari persepsi, attitude, personality, pembelajaran dan motivasi.

(3) faktor organisasi terdiri dari sumber daya, kepemimpinan, penghargaan, struktur, job design.

Pengukuran kinerja dapat digunakan beberapa ukuran kinerja. Beberapa ukuran kinerja yang meliputi:

(1) kuantitas kerja;

(2) kualitas kerja;

(3) pengetahuan tentang pekerjaan;

(4) kemampuan mengemukakan pendapat;

(5) pengambilan keputusan;

(6) perencanaan kerja dan daerah organisasi kerja.

Ukuran prestasi yang lebih disederhana terdapat tiga kriteria yaitu :

(1) kuantitas kerja, yaitu jumlah yang harus dikerjakan;

(2) kualitas kerja, yaitu mutu yang dihasilkan;

(3) ketepatan waktu, yaitu kesesuaiannya dengan waktu yang telah ditetapkan.

Pengukuran kinerja diarahkan pada enam aspek, yaitu hasil kerja, pengetahuan pekerjaan, inisiatif, kecekat-an mental, sikap, disiplin waktu dan absensi.

\section{B.6. Overall Labor Effectivenes (OLE)}

OLE mengukur ketersediaan (availability), kinerja (performance), dan kualitas (quality). Indikator pengukuran OLE adalah:

(1) ketersediaan (availability) adalah persentase waktu yang dihabiskan tenaga kerja dalam memberikan kontribusi efektif;

(2) kinerja (performance) adalah jumlah produk yang diserahkan;

(3) kualitas (quality) adalah persentase produk tanpa cacat (sempurna) yang diproduksi atau dapat dijual.

OLE membantu produsen untuk memahami kesalingtergantungan dan trade-off produktivitas di bagian produksi dan profitabilitas melalui pengukuran kontribusi dari tenaga kerja. OLE menganalisis pengaruh kumulatif dari ketiga faktor tenaga kerja (availability, performance, and quality) pada output yang dihasilkan, dengan 
mempertimbangkan tenaga kerja langsung dan tidak langsung.

\section{B.7. Mengukur Ketersediaan (Availability)}

Faktor yang mempengaruhi ketersediaan tenaga kerja seperti absensi, utilisasi, penjadwalan (scheduling), dan lain-lain. OLE dapat membantu produsen memberikan informasibahwa perusahaan tersebutmemilikitenaga kerja yang terampil, tersedia pada waktu yang tepat, sehingga memungkinkan produsen untuk menyiapkan penjadwalan tenaga kerja yang tepat untuk dapat meningkatkan jumlah jam produktif. OLE juga memberikan informasi tentang utilisasi tenaga kerja, kerugian downtime berasal dan dampak terhadap produksi.Ketersediaan (availability) merupakan komponen utama dalam perhitungan OLE.Utilisasi merupakan elemen yang paling penting dari availability.

\section{B.8. Mengukur Kinerja (Performance)}

Ketika tenaga kerja tidak dapat melakukan pekerjaan dalam waktu standar, maka kinerja akan menjadi rendah. Pelatihan yang efektif dapat meningkatkan kinerja melalui meningkatkan keterampilan yang berdampak langsung terhadap kualitas output. Akurasi pengukuran kinerja menggunakan OLE akan menentukan kesempatan peningkatan atau perbaikan kinerja sampai ke tingkat individu. Faktor pengendali dari kinerja (performance) antara lain ketersediaan proses, instruksi kerja, peralatan, material, pelatihan dan keterampilan, staf pendukung, dan lain-lain.

\section{B.9. Mengukur Kualitas (Quality)}

Sejumlah faktor pengendali berkontribusi terhadap kualitas, tetapi upaya untuk meningkatkan kualitas dapat mengakibatkan penurunan kinerja tenaga kerja.Faktor yang perlu dipertimbangkan untuk membuat korelasi antara tenaga kerja dan kualitas adalah pelatihan dan keterampilan tenaga kerja, tenaga kerja memiliki akses ke peralatan yang tepat untuk mengikuti prosedur, dan pemahaman tentang bagaimana perantenaga kerja mengendalikan kualitas [11]. OLE dapat membantu produsen menganalisis perubahan produktivitas, menentukan individu pekerja yang paling produktif, dan kemudian mengidentifikasi tindakan korektif yang sesuai untuk membawa operasi mencapai standar-standar kualitas yang telah ditetapkan [12].

\section{B.10. Diagram Pohon}

Diagram pohon (tree diagram) disebut juga diagram sistematik, analisis pohon, pohon analitis, atau diagram hirarkhi.Diagram Pohon adalah teknik untuk memetakan lengkap jalur dan tugas-tugas yang perlu dilakukan dalam rangka untuk mencapai tujuan utama dan tujuan sub terkait dengan sistematis [13].
Diagram Pohon dimulai dengan satu item yang cabang menjadi dua atau lebih, yang masingmasing cabang menjadi dua atau lebih, dan seterusnya. Hal ini digunakan untuk memecah kategori luas ke tingkat yang lebih halus dan detail. Cabang-cabang tersebut berfungsi untuk menjabarkan kategori-kategori yang bersifat umum menjadi level yang lebih detail. Diagram Pohon membantu menggambarkan langkah-langkah berpikir dari sesuatu yang umummenjadi sesuatu yang spesifik[14].

\section{METODOLOGI}

PT. "Y" merupakan pabrik crumb rubber yang proses produksinya berlangsung secara kontinyu atau terus-menerus selama 24 Jam/hari yang terdiri dari 3 shift. Shift 1 mulai dari pukul 07:00-15:00 dan shift II pukul 15:00-23:00, dan Shift III mulai dari pukul 23:00-07:00.

Data yang digunakan pada penelitian ini adalah data primer merupakan data yang diperoleh dari pengamatan dan penelitian secara langsung dilapangan. Pengumpulan data primer ini dilakukan dengan cara mengamati secara langsung di bagian produksi dan mewawancarai tenaga kerja yang terlibat langsung. Data yang digunakan pada penelitian ini adalahkehadiran tenaga kerja ,jumlah produksi, gross product dan defect product.

Langkah-langkah pengukuran efektifitas tenaga kerja dengan menggunakan metode Overall Labor Effectiveness (OLE) adalah:

(1) Menentuan nilai availability Availability $=100 \%$ - kehilangan jam kerja tenaga kerja (sakit, izin, absen)

(2) Menentukan nilai performance Performance $=100 \%$ - kehilangan waktu tidak memenuhi output standar

(3) Menentuan nilai quality Quality $=100 \%$ - kehilangan output karena cacat, defect, dan lain-lain

(4) Menentukan nilai OLE (Overall Labor Effectiveness)

OLE $=$ Availability $x$ Performance $x$ Quality

Setelah dilakukan pengolahan data, dilakukan analisa terhadap nilai availability, performance dan qualityserta OLE.Tahapan berikutnya adalah dengan menggunakanDiagram Pohon, dilakukan usulan peningkatan efektivitas tenaga kerja terhadap nilai OLE yang rendah.

\section{HASIL DAN PEMBAHASAN}

Jumlah produksi selama 1 tahun adalah crumb rubber $20.696 .571 \mathrm{~kg}$, produksi kering (gross product) $20.532 .386 \quad \mathrm{~kg}$, defect 164.185 kg.Jumlahkehadiran tenaga kerja adalah 12.104 orang. Nilai availability, performance, quality dan OLE tertinggi terdapat pada bulan Juli sebesar 92,9\% karena pada bulan tersebut jumlah tenaga kerja, jumlah produksi, dan gross product 
mengalami peningkatan yang sangat signifikan dibandingkan bulan lainnya. Nilai availability terendah terdapat pada bulan Agustus sebesar $54,2 \%$, performance terendah pada bulan November sebesar $62,9 \%$, quality terendah pada bulan Januari sebesar 98,8 \% dan OLE terendah terdapat pada bulan Agustus sebesar 72,9\%.

Analisa terhadap faktor yang memberikan kontribusi terbesar penyebab rendahnya efektivitas tenaga kerja persentase nilai dari OLE terendah yaitu pada bulan Agustus sebesar 72,9\%.

Faktor-faktor penyebab rendahnya efektivitas tenaga kerja adalah sebagai berikut:

(1) tenaga kerja kurang memanfaatkan waktu istirahat sehingga operatorkurang konsentrasi saat bekerja;

(2) tenaga kerja kurang teliti saat memilahbahanbaku yang akan diolah sehingga kualitas crumb rubberyang dihasilkan rendah;

(3) banyak tenaga kerja yang kehilangan jam kerja seperti disebabkan karena sakit, izin, tanpa keterangan, dan lain-lainnya sehingga jumlahproduksi crumb rubber berkurang.

Masih rendahnya nilai OLE maka perlu dilakukan evaluasi untuk mencari solusi dari permasalahan yang terjadi pada tenaga kerja di bagian produksi agar nilai OLE dapat ditingkatkan.

Usulan peningkatan efektivitas tenaga kerja dapat dikembangkan melalui langkah-langkah perbaikan terhadap faktor penghambat peningkatan efektivitas tenaga kerja.

Langkah-langkah yang dapat dilaksanakan untuk melakukan perbaikan faktor tenaga kerja antara lain:

(1) memberikan program pelatihan yang lebih efektif terhadap tenaga kerja baru maupun pekerja yang telah lama bekerja. Tujuan dari program pelatihan yang diberikan adalah untuk meningkatkan keterampilan tenaga kerja sebelum ditempatkan di stasiun kerja. Setelah ditempatkan di stasiun kerja hendaknya dilakukan evaluasi secara berkala untuk mengetahui sejauh mana keterampilan yang telah dimiliki oleh tenaga kerja;

(2) pihak manajemen seharusnya melakukan evaluasi terhadap penerapan dari studi waktu yang dilakukan di stasiun kerja sehingga mengetahui sejauh mana manfaat yang telah diperoleh dari hasil studi tersebut;

(3) penerapan sanksi yang lebih tegas terhadap tenaga kerja yang kurang disiplin.

Berikut uraian usulan pemecahan permasalahan untuk meningkatkan kinerja dan produktivitas tenaga kerja agar tingkat ketidakhadiran tenaga kerja dapat dikurangi adalah sebagai berikut:

(1) Rancangan kerja
Menetapkan tugas-tugas yang terkandung dalam suatu pekerjaan bagi seseorang atau sebuah kelompok tenaga kerja.

(a) Spesialisasi pekerjaan atau pembagian tenaga kerja.

- Meningkatkan ketangkasan dan pembelajaran karena adanya proses pengulangan.

- Pengembangan material handling khusus.

(b) Ekspansi pekerjaan yaitu variasi pekerjaan yang membuat pekerjaan jadi lebih baik dan tenaga kerja menikmati kualitas lingkungan kerja yang lebih baik.

- Pemekaran pekerjaan dilakukan pada saat tugas yang ditambahkan membutuhkan keahlian yang sama pada pekerjaan yang ada sekarang.

- Rotasi pekerjaan dilakukan pada saat tenaga kerja diperbolehkan berpindah dari satu pekerjaan ke pekerjaan lainnya.

- Pengayaan pekerjaan dengan cara menambahkan perencanaan dan pengendalian pekerjaan.

- Pemberdayaan pekerjaan merupakan praktik dalam memperkaya pekerjaan sehingga tenaga kerja menerima tanggung jawab untuk beragam keputusan. Cara ini berfungsi membantu tenaga kerja merasa memiliki pekerjaan hingga memiliki minat dalam diri sendiri untuk meningkatkan kinerja.

(c) Tim yang mandiri yaitu kelompok orang yang diberdayakan dan bekerja sama untuk meraih sebuah tujuan yang sama.

(2) Perencanaan tenaga kerja

(a) Kebijakan stabilitas tenaga kerja

- Permintaan tenaga kerja tepat

- Menjaga jumlah tenaga kerja konstan, dengan mempertahankan jumlah tenaga kerja konstan berarti perusahaan mempertahankan tenaga kerja yang terlatih.

(b) Jadwal kerja

- Flextime, dengan cara mengizinkan tenaga kerja untuk menentukan jadwal mereka masing-masing.

- Minggu kerja yang fleksibel yaitu dengan mengurangi jumlah hari kerja, tetapi jam kerja lebih panjang.

- Minggu kerja yang dipadatkan yaitu menyediakan tenaga kerja selama 24 jam.

- Paruh waktu

(c) Aturan kerja 


\section{E. KESIMPULAN}

Berdasarkan hasil yang diperoleh dan penetapan tujuan yang ingin dicapai, maka dapat disimpulkan hasil penelitian yang telah dilakukan sebagai berikut:

(1) Perhitungan nilai overall labor effectiveness (OLE)pada tenaga kerja produksi SIR di PT. "Y", maka didapat nilai dari overall labor effectiveness (OLE) tertinggi adalah pada bulan Juli yaitu 92,9\% sedangkan nilai overall labor effectiveness (OLE) terendah adalah pada bulan Agustus yaitu 72,9\%.

(2) Penyebab permasalahan kurangnya nilai OLE dan penyelesaiannya adalah:

(a) Nilai availability lebih rendah dibandingkan dengan nilai performance dan quality terutama pada bulan Agustus.

(b) Faktor tenaga kerja seharusnya mendapat perhatian lebih karena manusia merupakan bagian dari sistem kerja yang berperan sebagai variabel hidup, dengan berbagai sifat dan kemampuannya yang dapat memberi pengaruh besar terhadap keberhasilan usaha peningkatan efektifitas tenaga kerja.

(c) Penyebab permasalahan yang terjadi pada tenaga kerja adalah tingkat ketidakhadiran tenaga kerja yang tinggiyang mengakibatkan kurangnya produksi crumb rubber.

(d) Untuk melakukan penyelesaian masalah yang terjadi di perusahaan dalam upaya peningkatan kualitas proses produksi crumb rubber yaitu dengan melakukan pelatihan untuk tenaga kerja, memotivasi tenaga kerja dan pengawasan terhadap tenaga kerja. Selain itu untuk memenuhi target produksi dan menghasilkan produk yang sesuai dengan standar perusahaan sebaiknya dilakukan penempatan tenaga kerja yang sesuai dengan bidang atau keahliannya dan melakukan perencanaan kebutuhan tenaga kerja.

\section{REFERENSI}

[1] Yudhaningsih, R. April 2011. "Peningkatan Efektivitas Kerja Melalui Komitmen, Perubahan dan Budaya Organisasi.Jurnal Pengembangan Humaniora." Vol. 11 No. 1. April 2011

[2] Heizer, Jay dan Barry R. (2009). Manajemen Operasi. Jakarta: Salemba Empat

[3] Yudhaningsih, R. April 2011. "Peningkatan Efektivitas Kerja Melalui Komitmen, Perubahan dan Budaya Organisasi.Jurnal Pengembangan Humaniora." Vol. 11 No. 1. April 2011

[4] Gaspersz, V. (2013). All in One Integrated Total Quality Management. Bogor: Tri-Al-Bros Publishing

[5] Irawan, Prasetya, 2000. Manajemen Sumber Daya Manusia, STIA-LAN Press, Jakarta.

[6] Kartika, H., dan Tri H. (2011)“Analisa Pengaruh Sikap Kerja 5S dan Faktor Penghambat Penerapan 5S Terhadap Efektivitas Kerja Departemen Produksi di Perusahaan Sepatu". Jurnal Ilmiah PASTI. Volume V Edisi 1.

[7] Mangkunegara, Anwar Prabu. 2007. Evaluasi Kinerja SDM. Bandung: PT. Refika Aditama.

[8] Nasution, M, N. (2010). Manajemen Mutu Terpadu. Bogor: Ghalia Indonesia.

[9] Siagian, S.P. (1978). Manajemen. Yogyakarta: Liberty.

[10] Sutrisno, E. (2009). Manajemen sumber daya manusia. Jakarta: Kencana.

[11] Wibowo. (2007). Manajemen kinerja. Edisi Keempat. Jakarta: PT Raja Grafindo Persada.

[12] Zuliyati, S. (2005). "Pengaruh Pengembangan dan Pengawasan Terhadap Efektivitas Kerja Bagian Produksi PT. Tri Cahya Purnama Semarang". Skripsi Fakultas Ilmu Sosial. Universitas Negeri Semarang.

[13] Yamit, Z. (2003). Manajemen produksi. Yogyakarta: Ekonisia

[14] Yuri, T dan Rahmat N. 2010. TQM Manajemen Kualitas Total dalam Persektif Teknik Industri. Jakarta: PT. Indeks. 